\title{
White poplar (Populus alba L.) stands in Ukraine: the current state, growth specificities and prospects of using for forest plantations
}

\author{
Natalia Vysotska, Maksym Rumiantsev*, Oleksii Kobets \\ Ukrainian Research Institute of Forestry and Forest Melioration named after G. M. Vysotsky, \\ Pushkinska Str. 86, 61024, Kharkiv, Ukraine
}

\begin{abstract}
Vysotska, N., Rumiantsev, M., Kobets, O., 2021. White poplar (Populus alba L.) stands in Ukraine: the current state, growth specificities and prospects of using for forest plantations. Folia Oecologica, 48 (1): 63-72.

The aim of the study was to assess the current state and evaluate the productivity of white poplar stands by natural zones within Ukraine and to define the prospects for their use for plantation forest cultivation. The objects of the study were white poplar stands in Ukrainian forests grown on the area of more than 7,600 hectares in various natural zones, namely Polissya (forest zone in Ukraine), Forest-Steppe, and Steppe. The study was carried out based on the analysis of forest inventory data (Ukrainian forest fund database) containing given stand characteristics such as origin, age, diameter, height, type of forest site conditions, etc. The characteristics were estimated by grouping the plots by age. The growth specificities (dynamics of the main mensuration characteristics) and the productive capacity of the white poplar stands were analyzed based on the developed tables. It was found that white poplar stands are mainly concentrated in Steppe and Forest-Steppe in Ukraine. The stands are of coppice or artificial origin; they grow in moist fairly fertile, fresh fairly fertile and moist fertile sites. The age distribution of the white poplar stands is severely imbalanced due to a significant predominance of stands aged over 40 years in all natural zones within Ukraine. More productive are the white poplar stands growing within Polissya and Forest-Steppe. The developed growth and productivity tables should be used when planning and prioritizing the relevant forestry interventions in white poplar stands.
\end{abstract}

\section{Keywords}

mathematical models, productive capacity, short-rotation plantations, white poplar (Populus alba L.), yield tables

\section{Introduction}

Stands of white poplar (Populus alba L.) are of notable ecological and economic importance among the members of the genus Populus L. in the Ukrainian forests. They cover an area of more than 7,600 ha. They rank third among the poplar forests in terms of the area after the aspen (Populus tremula L.) (34,300 ha) and black poplar (Populus nigra L.) $(13,500 \mathrm{ha})$ stands (VYSOTSKA and TKACH, 2016). The study of poplar forests in Ukraine was initiated in the 1960s (Starova, 1962; LaVRinenKo et al., 1966; REDKo,
1975) and is continuing (TKACH, 1999; LAKIDA et al., 2011; Vysotska, 2017; VysotsKa and KoBets, 2018).

Populus alba L. is a widespread tree species (ZsuFfa, 1993; JaKucs, 2002; Global Invasive SPecies, 2015; TARAN and DYACHENKO, 2018). It is of commercial importance through the following biotechnological advantages: fairly rapid growth (HARFOUCHE et al., 2007; KATANić et al., 2015), a simple method of in vitro propagation (KLOPFENSTEIN et al., 1997; KALDORF et al., 2004), wide use in reclamative afforestation (EICHHORN et al., 2006), especially as windbreaks in plains, as well as

\footnotetext{
*Corresponding author:
} e-mail: maxrum-89@ukr.net 
for landscaping (IsHCHUK, 2016). It is also used in shortrotation forestry (KLAŠNJA et al., 2006) due to the high biomass accumulation as a result of the formation of deep root systems (Newman et al., 1997). White poplar stands are considered to be of superior productivity and wood quality to stands of other poplar species (MASHKINA et al., 2016; EHRST et al., 2019).

$P$. alba is an indigenous species in river floodplains; at the same time, it is intolerant to prolonged flooding. White poplar prefers moist and damp relatively fertile and fertile forest sites (BorodinA et al., 2008; GonZÁLEZ et al., 2010). It forms predominantly pure closed stands, which inhibits the growth of other trees and shrubs species by reducing the available sunlight, nutrients, and water (Global InVASIVE Species, 2015).

$P$. alba regenerates mainly by natural seed way. It often produces shoots from accessory buds (GonzÁLEZ et al., 2010; Korshikov et al., 2008; Global Invasive Species, 2015). Generally, artificial regeneration of poplar stands is used in plantation forestry.

Plantation forestry with the use of fast-growing species (including white poplar) is one of the ways to increase productivity and sustainability of forests, to intensify wood production, namely to improve wood quality, to reduce growing time and to increase yield per unit area (RUSIN, 2008; TsAREV et al., 2010). For example, poplar stands can produce technically suitable timber with a rotation period of 20 years or even less (TSAREv et al., 2010). Poplar wood is used as a raw material for biofuel production not only in Ukraine but elsewhere in the world (FILIMONOva, 1962; Corenblit et al., 2016; MAKsimenko et al., 2016; Holloway et al., 2017; Strenge et al., 2018).

The aim of the study was to assess the current state and to evaluate the productivity of white poplar stands by natural zones within Ukraine and define the prospects for their use for plantation forest cultivation.

\section{Materials and methods}

The objects of the study were white poplar stands in Ukrainian forests. They cover a total area of more than 7,600 hectares and grow in various natural zones, namely Polissya (forest zone in Ukraine), Forest-Steppe, and Steppe. The study covered pure and mixed stands of various origin, namely coppice, naturally regenerated from seeds and planted from seeds, within the white poplar range (Fig. 1).

The study was carried out based on analysis of forest management materials (database of Ukrainian forest fund), which contained certain forestry and mensuration characteristics of stands (origin, age, diameter, height, type of forest site conditions, etc.). To analyze the forest area of white poplar stands, we developed an electronic subcompartment database using the forest inventory data of the Ukrderzhlisproekt Production Association as on 2016, then converted it from the .vff into .mdb format of MS Access by means of the NewUnPackOHOTA programme developed in the Laboratory of New Information Technologies of the Ukrainian Research
Institute of Forestry and Forest Melioration (URIFFM). Data selection necessary for the further calculations was exported into the .xls format in Microsoft Excel 2016 in compliance with the developed algorithm (VEDMID et al., 2006). The stand characteristics were estimated by grouping the plots by age.

The growth specificities (dynamics of the main mensuration characteristics) and the productive capacity of the white poplar stands were analyzed based on the developed tables. Mathematical modeling of poplar stand growth was carried out according to previously tested methods (ANUCHIN, 1982; LAKIDA et al., 2006; MiKLUSH, 2007; Hrom, 2010) using forest management materials and mathematical statistics methods (LAPACH et al., 2001). About 3,400 survey plots in white poplar stands have been analyzed to provide sufficient sampling for the construction of mathematical models of growth. We developed an electronic subcompartment database using the forest inventory data including 150 survey plots in Polissya zone, 1,550 survey plots in the Forest-Steppe and 1,700 survey plots in the Steppe zone.

An important indicator for determining the course of growth is the average height of the stand since it is related to the other parameters; it has less variation than other stand characteristics. The Mitcherlich function was applied to model the height. This function is widely used in modeling stand growth processes (LAKIDA et al., 2006). The age of 25 years was used as a basic one because white poplar stands have the maximum stock volume at this age.

The typological analysis of forests was done in compliance with the main methodical statements of the forest-ecological (Ukrainian) school of the forest typology (Ostapenko and TKaCh, 2002; Migunova, 2014; 2017).

\section{Results}

About half of the white poplar stands area in the forest fund of Ukraine are concentrated in Steppe $-49.4 \%$. Their area in Forest-Steppe is $42.4 \%$ and in Polissya $8.2 \%$ only. By origin, stands naturally regenerated from seeds predominate in Polissya; their area is $55.8 \%$. ForestSteppe and Steppe zones are dominated by stands of vegetative (coppice) origin, with $42.4 \%$ and $47.5 \%$ of the area, respectively. In general, the forests of the country are dominated by white poplar stands of vegetative origin $(42.8 \%)$ and those regenerated artificially from seeds $(31.0 \%)$ (Table 1). However, it should be noted that stands of vegetative origin have significantly lower productivity compared to artificial stands planted from seeds.

The age distribution of the white poplar stands is severely imbalanced. The analysis of forest management materials indicates a significant predominance of stands aged over 40 years in all natural zones within Ukraine. For example, in Polissya, their area is $76-83 \%$ depending on the origin. They cover $57-77 \%$ in Forest-Steppe and $77-$ $87 \%$ in the Steppe (Table 2). Such stands rapidly lose their ecological functions. They need to be gradually replaced to continue to perform the essential environmental and protective functions effectively. 


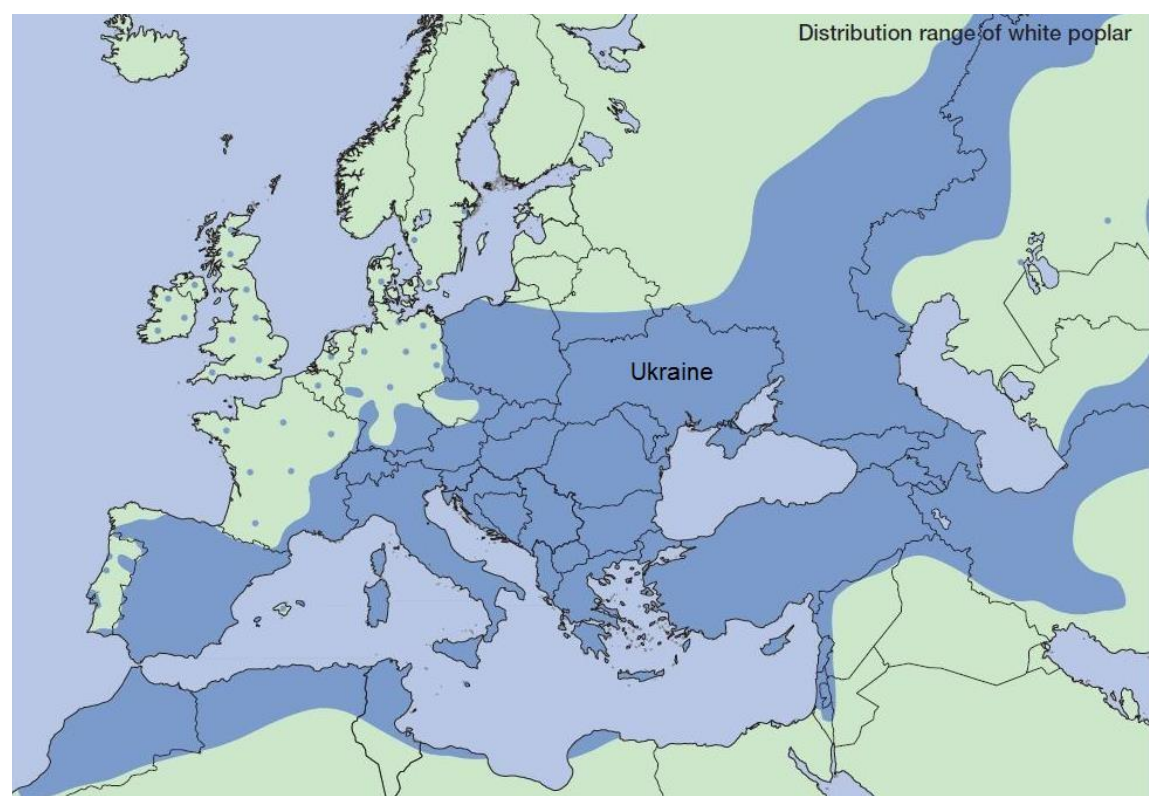

Fig. 1. Distribution map of White poplar (Populus alba) (PALANCEAN et al., 2018).

Table 1. Distribution of the area of white poplar stands in the forest fund of Ukraine by origin within the natural zones

\begin{tabular}{|c|c|c|c|c|c|}
\hline \multirow{3}{*}{ Natural zones } & \multirow{3}{*}{ Units } & \multicolumn{4}{|c|}{ Origin } \\
\hline & & \multicolumn{2}{|c|}{ Natural } & \multirow{2}{*}{$\begin{array}{c}\text { Artificial from } \\
\text { seed }\end{array}$} & \multirow{2}{*}{ Total } \\
\hline & & vegetative & seed & & \\
\hline \multirow{2}{*}{ Polissya } & ha & 100.1 & 350.6 & 178.1 & 628.8 \\
\hline & $\%$ & 15.9 & 55.8 & 28.3 & 100.0 \\
\hline \multirow{2}{*}{ Forest-Steppe } & ha & $1,371.1$ & 976.4 & 884.4 & $3,231.9$ \\
\hline & $\%$ & 42.4 & 30.2 & 27.4 & 100.0 \\
\hline \multirow{2}{*}{ Steppe } & ha & $1,791.3$ & 674.6 & $1,303.0$ & $3,768.9$ \\
\hline & $\%$ & 47.5 & 17.9 & 34.6 & 100.0 \\
\hline \multirow{2}{*}{ Total forest fund of Ukraine } & ha & $3,262.5$ & $2,001.6$ & $2,365.5$ & $7,629.6$ \\
\hline & $\%$ & 42.8 & 26.2 & 31.0 & 100.0 \\
\hline
\end{tabular}

Most white poplar stands grow in moist relatively fertile sites. For example, the proportion of the stands in this forest site type is $76 \%$ for Polissya, $32 \%$ for ForestSteppe, and $28 \%$ for the whole of Ukraine. The Steppe is dominated by stands in moist fertile sites $(32 \%)$. In this natural zone, the proportion of stands growing in moist relatively fertile sites is $16 \%$. Stands in moist fertile sites are also common in Forest-Steppe and Steppe; they make $31 \%$ and $16 \%$ respectively (Table 3 ).

To develop mathematical models for modal stands' growth, it is essential to determine the correlations between weighted averages of their mensuration characteristics. We defined the direction and strength of relationships between mensuration metrics used the correlation coefficients (Table 4). There were strong positive relationships between age $(A)$, height $(H)$, diameter $(D)$, the sum of crosssectional areas per 1 ha $(G)$ and stock volume per 1 ha $(M)$. The relationships between those stand characteristics and the stand density $(N)$ were either strong negative or very strong negative.
The following functions (1-3) are selected to approximate the average height of modal stands:

$$
\begin{gathered}
H_{\text {Polissya }}=2.13 \times\left(1-e^{-0.027 \times A}\right)^{1.06} \times H_{25}^{B A S} \\
H_{\text {Forest-Steppe }}=2.23 \times\left(1-e^{-0.024 \times A}\right)^{1.01} \times H_{25}^{B A S} \\
H_{\text {Steppe }}=2.22 \times\left(1-e^{-0.025 \times A}\right)^{1.04} \times H_{25}^{B A S}
\end{gathered}
$$

Using the Mitcherlich function, we modeled the height dynamics for the white poplar stands. According to the developed mathematical relationships, stands growing within the Polissya zone have slightly greater heights compared to stands within the Forest-Steppe and Steppe (Fig. 2). The difference is $2-9 \%$.

The average diameter is mostly influenced by age and height, so the diameter to height ratio $(\mathrm{D} / \mathrm{H})$ approximated by functions (4-6) was used to model the average diameter: 
${\frac{D}{H_{\text {Polissya }}}}=-0.000024 \times A^{2}+0.0095 \times A+1.094, \quad R^{2}=0.90$

${\frac{D}{H_{\text {Forest-Steppe }}}}=0.000055 \times A^{2}+0.0115 \times A+1.05, \quad R^{2}=0.92 \quad$ (5)

$\frac{D}{H}_{\text {Steppe }}=-0.000128 \times A^{2}+0.014 \times A+1.041, \quad R^{2}=0.83$
One of the main stand characteristics is the sum of the cross-sectional areas of trunks $(G)$. We have adopted it in accordance with the regulatory reference materials for poplar stands (KASHPOR and STROCHINSKIY, 2013). It is approximated by the function (7):

Table 2. Distribution of the area of white poplar stands by 10 year age classes in natural zones

\begin{tabular}{|c|c|c|c|c|c|c|}
\hline \multirow{3}{*}{$\begin{array}{c}\text { Age range, } \\
\text { years }\end{array}$} & \multicolumn{6}{|c|}{ Natural zones } \\
\hline & \multicolumn{2}{|c|}{ Polissya } & \multicolumn{2}{|c|}{ Forest-Steppe } & \multicolumn{2}{|c|}{ Steppe } \\
\hline & ha & $\%$ & ha & $\%$ & ha & $\%$ \\
\hline \multicolumn{7}{|c|}{ Vegetative regeneration } \\
\hline $1-10$ & 17.9 & 17.9 & 177.0 & 12.9 & 51.7 & 2.9 \\
\hline $11-20$ & 1.5 & 1.5 & 110.5 & 8.1 & 117.2 & 6.5 \\
\hline $21-30$ & 1.3 & 1.3 & 141.0 & 10.3 & 89.9 & 5.0 \\
\hline $31-40$ & 1.5 & 1.5 & 147.3 & 10.7 & 42.4 & 2.4 \\
\hline $41-50$ & 1.7 & 1.7 & 191.0 & 13.9 & 210.9 & 11.8 \\
\hline $51-60$ & 26.6 & 26.6 & 191.2 & 14.0 & 313.1 & 17.4 \\
\hline $61-70$ & 1.3 & 1.3 & 240.1 & 17.5 & 218.1 & 12.2 \\
\hline $71-80$ & 9.3 & 9.3 & 94.9 & 6.9 & 373.8 & 20.9 \\
\hline $81-90$ & - & - & 74.8 & 5.5 & 145.5 & 8.1 \\
\hline $91-100$ & 39.0 & 38.9 & 2.8 & 0.2 & 141.5 & 7.9 \\
\hline $101-110$ & - & - & 0.5 & - & 87.2 & 4.9 \\
\hline Total & 100.1 & 100.0 & $1,371.1$ & 100.0 & $1,791.3$ & 100.0 \\
\hline \multicolumn{7}{|c|}{ Natural regeneration from seed } \\
\hline $1-10$ & 9.2 & 2.6 & 28.8 & 3.0 & 17.4 & 2.6 \\
\hline $11-20$ & - & - & 26.0 & 2.7 & 19.9 & 2.9 \\
\hline $21-30$ & 14.7 & 4.2 & 34.6 & 3.5 & 26.2 & 3.9 \\
\hline $31-40$ & 26.1 & 7.4 & 103.6 & 10.6 & 23.6 & 3.5 \\
\hline $41-50$ & 72.8 & 20.8 & 233.2 & 23.9 & 68.3 & 10.1 \\
\hline $51-60$ & 98.1 & 28.0 & 219.9 & 22.5 & 155.5 & 23.1 \\
\hline $61-70$ & 87.0 & 24.8 & 159.5 & 16.3 & 160.9 & 23.8 \\
\hline $71-80$ & 42.7 & 12.2 & 112.4 & 11.5 & 139.6 & 20.7 \\
\hline $81-90$ & - & - & 51.0 & 5.2 & 29.0 & 4.3 \\
\hline $91-100$ & - & - & 7.4 & 0.8 & 7.8 & 1.2 \\
\hline $101-110$ & - & - & - & - & 26.4 & 3.9 \\
\hline Total & 350.6 & 100.0 & 976.4 & 100.0 & 674.6 & 100.0 \\
\hline \multicolumn{7}{|c|}{ Artificial regeneration from seed } \\
\hline $1-10$ & - & - & 19.0 & 2.2 & 3.4 & 0.3 \\
\hline $11-20$ & 1.5 & 0.8 & 38.3 & 4.3 & 15.6 & 1.2 \\
\hline $21-30$ & 18.9 & 10.6 & 31.8 & 3.6 & 108.4 & 8.3 \\
\hline $31-40$ & 6.7 & 3.8 & 106.0 & 12.0 & 159.0 & 12.2 \\
\hline $41-50$ & 126.1 & 70.8 & 491.2 & 55.5 & 712.5 & 54.7 \\
\hline $51-60$ & 22.2 & 12.5 & 139.1 & 15.7 & 226.2 & 17.4 \\
\hline $61-70$ & 2.2 & 1.2 & 45.8 & 5.2 & 42.1 & 3.2 \\
\hline $71-80$ & 0.5 & 0.3 & 11.3 & 1.3 & 18.5 & 1.4 \\
\hline $81-90$ & - & - & 1.9 & 0.2 & 14.7 & 1.1 \\
\hline $91-100$ & - & - & - & - & 2.3 & 0.2 \\
\hline $101-110$ & - & - & - & - & 0.3 & - \\
\hline Total & 178.1 & 100.0 & 884.4 & 100.0 & $1,303.0$ & 100.0 \\
\hline
\end{tabular}


Table 3. Distribution of the area of white poplar stands by types of forest site conditions in natural zones

\begin{tabular}{|c|c|c|c|c|c|c|c|c|}
\hline \multirow{3}{*}{ Forest site types } & \multicolumn{6}{|c|}{ Natural zones } & \multirow{2}{*}{\multicolumn{2}{|c|}{$\begin{array}{c}\text { Total forest fund } \\
\text { of Ukraine }\end{array}$}} \\
\hline & \multicolumn{2}{|c|}{ Polissya } & \multicolumn{2}{|c|}{ Forest-Steppe } & \multicolumn{2}{|c|}{ Steppe } & & \\
\hline & ha & $\%$ & ha & $\%$ & ha & $\%$ & ha & $\%$ \\
\hline $\begin{array}{l}\text { Fresh relatively poor pine site } \\
\text { type }\left(\mathrm{B}_{2}\right)\end{array}$ & 2.3 & 0.4 & 43.0 & 1.3 & 160.6 & 4.3 & 205.9 & 2.7 \\
\hline $\begin{array}{c}\text { Moist relatively poor pine site } \\
\text { type }\left(\mathrm{B}_{3}\right)\end{array}$ & 59.2 & 9.4 & 143.6 & 4.5 & 188.4 & 5.0 & 391.2 & 5.1 \\
\hline $\begin{array}{l}\text { Fresh relatively fertile site } \\
\text { type }\left(\mathrm{C}_{2}\right)\end{array}$ & 32.0 & 5.1 & 954.0 & 29.5 & 592.9 & 15.7 & $1,578.9$ & 20.7 \\
\hline $\begin{array}{l}\text { Moist relatively fertile site } \\
\text { type }\left(\mathrm{C}_{3}\right)\end{array}$ & 479.1 & 76.2 & $1,015.7$ & 31.4 & 606.5 & 16.1 & $2,101.3$ & 27.5 \\
\hline $\begin{array}{l}\text { Damp relatively fertile site } \\
\text { type }\left(\mathrm{C}_{4}\right)\end{array}$ & 16.3 & 2.6 & 110.5 & 3.4 & 289.7 & 7.7 & 416.5 & 5.5 \\
\hline Fresh fertile site type $\left(D_{2}\right)$ & 25.9 & 4.1 & 298.2 & 9.2 & 474.8 & 12.6 & 798.9 & 10.5 \\
\hline Moist fertile site type $\left(\mathrm{D}_{3}\right)$ & 3.4 & 0.5 & 571.6 & 17.7 & $1,195.6$ & 31.7 & $1,770.6$ & 23.2 \\
\hline Other forest site types & 10.6 & 1.7 & 95.3 & 3.0 & 260.4 & 6.9 & 366.3 & 4.8 \\
\hline Total & 628.8 & 100.0 & $3,231.9$ & 100.0 & $3,768.9$ & 100.0 & $7,629.6$ & 100.0 \\
\hline
\end{tabular}

Table 4. Correlation matrix of mensuration characteristics of white poplar stands

\begin{tabular}{|c|c|c|c|c|c|c|}
\hline $\begin{array}{l}\text { Mensuration } \\
\text { characteristics }\end{array}$ & $A$ (years) & $H(\mathrm{~m})$ & $D(\mathrm{~cm})$ & $\begin{array}{c}N \\
\left(\text { stems ha }^{-1}\right)\end{array}$ & $\begin{array}{c}G \\
\left(\mathrm{~m}^{2} \mathrm{ha}^{-1}\right)\end{array}$ & $\begin{array}{c}M \\
\left(\mathrm{~m}^{3} \mathrm{ha}^{-1}\right)\end{array}$ \\
\hline \multicolumn{7}{|c|}{ Polissya and Forest-Steppe (in grey) } \\
\hline$A$ (years) & 1 & 0.975 & 0.994 & -0.769 & 0.873 & 0.980 \\
\hline$H(\mathrm{~m})$ & 0.979 & 1 & 0.994 & -0.874 & 0.957 & 0.998 \\
\hline$D(\mathrm{~cm})$ & 0.993 & 0.996 & 1 & -0.822 & 0.919 & 0.996 \\
\hline$N\left(\right.$ stems ha $\left.{ }^{-1}\right)$ & -0.784 & -0.881 & -0.837 & 1 & -0.968 & -0.846 \\
\hline$G\left(\mathrm{~m}^{2} \mathrm{ha}^{-1}\right)$ & 0.897 & 0.968 & 0.940 & -0.961 & 1 & 0.942 \\
\hline$M\left(\mathrm{~m}^{3} \mathrm{ha}^{-1}\right)$ & 0.982 & 0.998 & 0.997 & -0.851 & 0.955 & 1 \\
\hline \multicolumn{7}{|c|}{ Steppe } \\
\hline$A$ (years) & 1 & - & - & - & - & - \\
\hline$H(\mathrm{~m})$ & 0.978 & 1 & - & - & - & - \\
\hline$D(\mathrm{~cm})$ & 0.979 & 0.999 & 1 & - & - & - \\
\hline$N\left(\right.$ stems ha $\left.^{-1}\right)$ & -0.778 & -0.878 & -0.865 & 1 & - & - \\
\hline$G\left(\mathrm{~m}^{2} \mathrm{ha}^{-1}\right)$ & 0.921 & 0.980 & 0.974 & -0.953 & 1 & - \\
\hline$M\left(\mathrm{~m}^{3} \mathrm{ha}^{-1}\right)$ & 0.989 & 0.997 & 0.998 & -0.837 & 0.961 & 1 \\
\hline
\end{tabular}

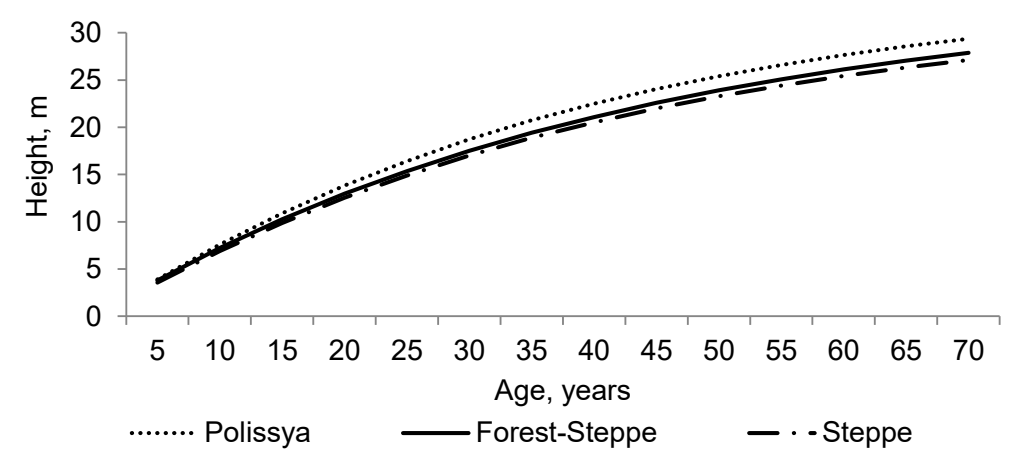

Fig. 2. Dynamic changes in height of planted modal stands of white poplar. 
$G=-0.0408 \times A^{2}+3.385 \times A-4.271$,

$R^{2}=0.99$

(7)

We used forest management materials and data from the sample plots to determine the density of the stands. The dynamics of the relative density of stocking are described by second-order polynomial functions $(8-10)$ :

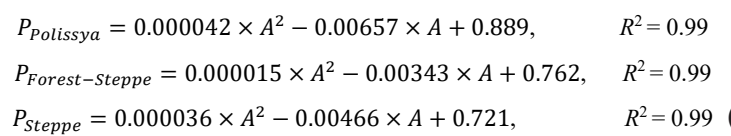

Simulation of the dynamics of tree form factors was performed using form height (HF). The dependence of form heights on age is described by third-order polynomials (11-13):

$$
\begin{array}{r}
H F_{\text {Polissya }}=0.000014 \times A^{3}-0.00359 \times A^{2}+0.361 \times A+0.608, \\
R^{2}=0.99 \\
H F_{\text {Forest-Steppe }}=0.000023 \times A^{3}-0.00468 \times A^{2}+0.392 \times A, \\
R^{2}=0.99 \\
H F_{\text {Steppe }}=0.000021 \times A^{3}-0.0044 \times A^{2}+0.379 \times A, \quad R^{2}=0.99
\end{array}
$$

The rest of the parameters for the stands were determined by the formulas accepted in forest taxation (ANUCHIN, 1982; Hrom, 2010). Determination coefficients in the range of $0.83-0.99$ indicate a high validity of the determined dependencies. Therefore, they were used to create yield and productivity/capacity tables for white poplar stands.

Taking into account the predominance - and sufficient representation in Steppe - of the moist relatively fertile sites, the corresponding tables were developed describing the growth patterns (dynamics of the main stand characteristics) and the productive capacity of white poplar stands in this type of forest site conditions, a sketch of which is presented in Table 5 .

\section{Discussion}

\section{The productive capacity of poplar stands}

According to the constructed yield tables, the most productive are the modal stands of Polissya. Their stock volume reaches $492 \mathrm{~m}^{3} \mathrm{ha}^{-1}$ at the age of 70 . The stock volume of poplar stands in Forest-Steppe and Steppe is much smaller at the base age (70 years), $427 \mathrm{~m}^{3} \mathrm{ha}^{-1}$, and $394 \mathrm{~m}^{3} \mathrm{ha}^{-1}$, respectively. Relative indicators of the stands in Polissya exceed those of the stands in Forest-Steppe and the Steppe by $13-31 \%$ and $20-44 \%$, respectively. This difference gradually decreases with age (Fig. 3). ForestSteppe stands have $8-18 \%$ higher productive capacity than Steppe stands. The difference also decreases with age.

The poplar stands in Polissya have 9-13\% lower stock volume when compared to the growth data of the white poplar stands in the Don floodplain (ERMOLOvA, 2015). For Forest-Steppe, the difference is $24-32 \%$ and Steppe, $30-44 \%$

\section{Growing poplars in plantations}

In the world, poplar stands are often grown as dense plantations with short rotation periods (KLAŠNJA et al., 2006; RÉDEI et al., 2006; ANDRIYCHUK, 2007; FANG et al., 2007; Rusin, 2008; TsAReV et al., 2010; FuChYLO et al., 2014; RÉDEI et al., 2012; TulLus et al., 2012; WANG et al., 2014; MashKina et al., 2016), mainly on soils not suitable for growing crops. Such plantations have high biomass yield per unit area. Fluctuations in the current increment of poplar plantations on an industrial scale in Sweden, the United Kingdom, Italy, Belgium, Germany, Poland, Spain, and the USA are within 5-13 $\mathrm{m}^{3} \mathrm{ha}^{-1}$ per year on average, sometimes even up to $36 \mathrm{~m}^{3} \mathrm{ha}^{-1}$ per year (SCHWEIER, 2012; Tullus et al., 2012; HeNRIKSSON and HeNRIKSSON, 2015; LINDEGAARD et al., 2016). That should be taken into account when growing poplar plantations (FUCHYLO et al., 2014). Particularly relevant is the introduction of plantations on land unsuitable for agriculture, of which there are about 10 million hectares in Ukraine (KRAVCHUK et al., 2013).

RYTTER et al. (2011) showed that poplar plantations, including white poplars, were as cost-effective as cultivation of Norway spruce (Picea abies (L.) Karsten) in forest land and various grain and industrial crops on agricultural land in Sweden. In Estonia (Tullus et al., 2012), hybrid poplar plantations were found to have higher profitability than silver birch (Betula pendula Roth.) and other species planted on formerly arable land. Researchers from Canada (Stanturf et al., 2001) and Serbia (KEČA et al., 2012) came to similar conclusions. According to their data, the profitability of poplar plantations is higher than

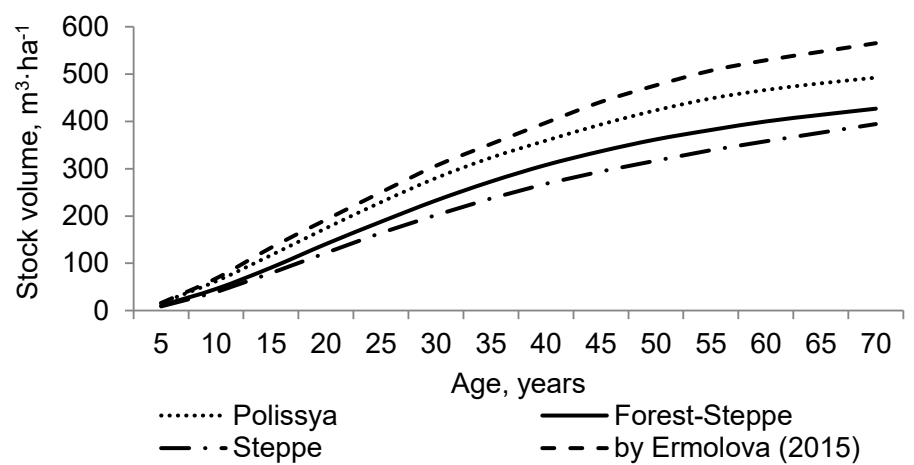

Fig. 3. Dynamics of stock volumes of white poplar stands. 
Table 5. Sketch of yield and productive capacity tables for white poplar stands in moist relatively fertile type of forest site conditions in various natural zones of Ukraine

\begin{tabular}{|c|c|c|c|c|c|c|c|c|}
\hline \multirow{4}{*}{$\begin{array}{c}A \\
\text { (years) }\end{array}$} & \multicolumn{8}{|c|}{ Tree stand indicators } \\
\hline & \multirow{3}{*}{$H(\mathrm{~m})$} & \multirow{3}{*}{$D(\mathrm{~cm})$} & \multirow{3}{*}{$\begin{array}{c}N \\
\left(\text { stems ha }^{-1}\right)\end{array}$} & \multirow{2}{*}{$\begin{array}{c}G \\
\left(\mathrm{~m}^{2} \mathrm{ha}^{-1}\right)\end{array}$} & \multirow{3}{*}{$f$} & \multirow{3}{*}{$\begin{array}{c}M \\
\left(\mathrm{~m}^{3} \mathrm{ha}^{-1}\right)\end{array}$} & \multicolumn{2}{|c|}{$\Delta M\left(\mathrm{~m}^{3} \mathrm{ha}^{-1}\right.$ year $\left.^{-1}\right)$} \\
\hline & & & & & & & average & actual \\
\hline & & & & \multicolumn{3}{|l|}{ Polissya } & & \\
\hline 10 & 7.6 & 9.0 & 2,484 & 15.9 & 0.509 & 62 & 6.2 & 9.2 \\
\hline 20 & 13.8 & 17.6 & 1,099 & 26.7 & 0.471 & 174 & 8.7 & 11.4 \\
\hline 30 & 18.7 & 25.4 & 645 & 32.7 & 0.458 & 280 & 9.3 & 10.2 \\
\hline 40 & 22.5 & 32.4 & 428 & 35.3 & 0.452 & 359 & 9.0 & 7.2 \\
\hline 50 & 25.4 & 38.4 & 320 & 37.1 & 0.449 & 423 & 8.5 & 6.0 \\
\hline 60 & 27.6 & 43.6 & 253 & 37.8 & 0.447 & 466 & 7.8 & 3.6 \\
\hline 70 & 29.3 & 48.2 & 207 & 37.7 & 0.445 & 492 & 7.0 & 2.4 \\
\hline \multicolumn{9}{|c|}{ Forest-Steppe } \\
\hline 10 & 7.2 & 8.4 & 2,382 & 13.1 & 0.483 & 46 & 4.6 & 7.0 \\
\hline 20 & 13.0 & 16.3 & 1,096 & 22.9 & 0.475 & 141 & 7.1 & 10.0 \\
\hline 30 & 17.5 & 23.5 & 657 & 28.5 & 0.468 & 233 & 7.8 & 9.0 \\
\hline 40 & 21.1 & 30.0 & 450 & 31.8 & 0.459 & 308 & 7.7 & 7.0 \\
\hline 50 & 23.9 & 35.6 & 338 & 33.6 & 0.452 & 362 & 7.2 & 5.0 \\
\hline 60 & 26.1 & 40.3 & 269 & 34.3 & 0.446 & 400 & 6.7 & 3.6 \\
\hline 70 & 27.9 & 44.2 & 225 & 34.5 & 0.444 & 427 & 6.1 & 2.6 \\
\hline \multicolumn{9}{|c|}{ Steppe } \\
\hline 10 & 6.9 & 8.0 & 2,320 & 11.6 & 0.489 & 39 & 3.9 & 6.0 \\
\hline 20 & 12.5 & 15.9 & 1,025 & 20.4 & 0.476 & 122 & 6.1 & 8.6 \\
\hline 30 & 17.0 & 22.9 & 619 & 25.5 & 0.467 & 202 & 6.7 & 7.6 \\
\hline 40 & 20.5 & 28.6 & 444 & 28.5 & 0.458 & 268 & 6.7 & 6.2 \\
\hline 50 & 23.3 & 33.0 & 354 & 30.3 & 0.450 & 317 & 6.3 & 4.6 \\
\hline 60 & 25.4 & 36.1 & 310 & 31.7 & 0.444 & 358 & 6.0 & 3.8 \\
\hline 70 & 27.1 & 37.7 & 295 & 32.9 & 0.442 & 394 & 5.6 & 3.6 \\
\hline
\end{tabular}

that of Manchurian red pine (Pinus tabuliformis Carr.), Norway spruce, and black walnut (Juglans nigra L.) (WANG et al., 2014).

The increase in the area of plantations with short rotation period (including white poplar) around the world is due to the need to reduce the area of land used for food production, as well as environmental benefits of renewable energy, and grants for afforestation of former agricultural land (WANG et al., 2014).

Poplars (Populus spp.) are increasingly used in many European countries for the short-rotation plantations for biomass production as a sustainable energy source (TuLLUS et al., 2012). For example, in Italy, poplar plantations cover an area of over 100,000 ha (FANG et al., 2007). In Sweden, energy crop plantations cover more than 20,000 ha (KravchuK et al., 2013). Poplar plantations cover 13.5\% of the total forested area in China (WILSKE et al., 2009). In Poland, over 200 cultivars of poplars and willows are used in plantation forestry (ANDRIYCHUK, 2007).
P. alba $\mathrm{L}$. is one of the main forest-forming species in Hungarian forests, occupying $3.4 \%$ or about 64,000 ha of the total area (RÉDEI et al., 2006; 2010; 2012) and REBOLALICHTENBERG et al. (2019) have proved that the addition of $20-30 \%$ of Robinia pseudoacacia L. in the composition of white poplar plantations leads to mutual advantages.

The feature of Ukrainian forestry is mainly the environmental significance of forests and the high proportion, up to $50 \%$, of the forests of limited exploitation, as well as a significant proportion, $15.8 \%$, of reserved forests, which has a steady upward trend. Therefore, it is important to normalize the balance between the consumption of timber resources and the regeneration of forests. One way of doing this is to establish plantations of fast-growing tree species, which will significantly increase the volume of small-scale production.

When selecting a site to establish a white poplar plantation, the ecological range of white poplar is to be considered. The humidity limit of the ecological range is arid soil. 


\section{Conclusions}

Among the members of genus Populus L., the white poplar (Populus alba L.) stands rank third in the Ukrainian forests in terms of area (7,600 ha) behind the aspen (Populus tremula L.) (34,300 ha) and black poplar (Populus nigra L.) $(13,500 \mathrm{ha})$ stands. $P$. alba is an indigenous species in the floodplains of rivers; however, it is intolerant of prolonged flooding. In Ukraine, white poplar stands are mainly concentrated in Steppe and Forest-Steppe. They are coppice and planted stands growing in moist and fresh relatively fertile sites and moist fertile sites.

About half of the white poplar stands in the forests of Ukraine are concentrated in the Steppe zone, making $49.4 \%$. The stands cover $42.4 \%$ in the Forest-Steppe zone and only $8.2 \%$ in Polissya. The stands of natural seed origin predominate in Polissya (55.8\%) and stands of coppice origin in the Forest-Steppe and Steppe zones (42.4\% and $47.5 \%$, respectively).

The age distribution of the white poplar stands is severely imbalanced due to the predominance of stands aged over 40 years in all natural zones within Ukraine.

The most productive are the modal stands in Polissya. Their stock volume reaches $492 \mathrm{~m}^{3} \mathrm{ha}^{-1}$ at the age of 70 . The stock volume of poplar stands in Forest-Steppe and Steppe is much smaller at the base age (70 years), $427 \mathrm{~m}^{3}$ $\mathrm{ha}^{-1}$ and $394 \mathrm{~m}^{3} \mathrm{ha}^{-1}$, respectively.

The developed growth and productivity tables should be used when planning and prioritizing the relevant forestry interventions in white poplar stands.

\section{Acknowledgements}

This work contains results from the scientific project "To study growth and development of forest crops planted with containerized planting material and to develop recommendations on how to improve the technology of their establishment" (grant 0120U101897), which was supported by the State Forest Resources Agency of Ukraine. The authors are grateful to the staff of the Laboratory of Silviculture and Forest Melioration and of Forestry of the Ukrainian Research Institute of Forestry and Forest Melioration named after G. M. Vysotsky for their support and assistance with this research. The authors would like to thank the Executive Editor, the Editor of the manuscript, and the anonymous reviewers for helping to improve the earlier versions of this paper.

\section{References}

ANDRIYCHUK, V.G., 2007. Enerhobezpeka: enerhozberezhennya i napryamy dyversyfikatsiyi enerhopostachannya (u konteksti perspektyvy vzayemodiyi Ukrayiny ta Polshchi) [Energy security: energy saving and directions of energy supply diversification (in the context of Ukraine and Poland interaction prospect)]. Economic Annals-XXI, 7-8. [cit. 2020-04-29]. http://soskin.info/ea/2007/7-8/200703. html
ANUChIN, N.P., 1982. Lesnaya taksatsiya [Forest inventory]. Moskva: Lesnaya promyshlennost'. 552 p.

Borodina, N.V., Kovalev, V.V., Rudnik, A.M., Emelyanova, I.V., 2008. Farmakohnostychne doslidzhennya lystya Populus alba L. [Pharmacognostic research of Populus alba L.]. Zaporizhzhya Medical Journal, 2 (47): 170-172

Corenblit, D., Steiger, J., Charrier, G., Darrozes, J., Garófano-Gómez, V., Garreau, A., Lambs, L., 2016. Populus L. establishment and fluvial landform construction: biogeomorphic dynamics within a channelized river. Earth Surface Processes and Landforms, 41 (9): 1276-1292. https://doi.org/10.1002/esp.3954

Ehrst, A.A., ShishKin, S.V., Voronkova, M.S., 2019. Polucheniye mezhvidovyh hibridov (Populus alba $\times$ P. bolleana $) \times P$. $\times$ canescens $s$ ispolzovaniyem kultury in vitro [The generation of interspecific hybrids in (Populus alba $\times$ P. bolleana) $\times$ P. canescens by in vitro culture]. Sibirian Journal of Forest Science, 2: 45-52. https://doi. org/10.15372/SJFS20190204

EichHorn, M.P., Paris, P., Herzog, F., Incoll, L.D., Liagre, F., Mantzanas, K., Mayus, M., Moreno, G., Papanastasis, V.D.J., Pilbeam, D., Pisanelli, A., Dupraz, C., 2006. Silvoarable systems in Europe - past, present and future prospects. Agroforestry Systems, 67 (1): 29-50. https://doi.org/10.1007/s10457-005-1111-7

ERmolova, A.S., 2015. Sostoyaniye, rost i resursnyy potentsial nasazhdeniy topolya belogo $v$ poymah rek Stepnogo Pridonya [Condition, growth and resource potential of white poplar plants in the floodplains of the Steppe Pridonje rivers]. PhD thesis. Pushkino: VNIILM. 198 p.

FAng, S. Xue, J., TANG, L., 2007. Biomass production and carbon sequestration potential in poplar plantations with different management patterns. Journal of Environmental Management, 85 (3): 672-679. https://doi.org/10.1016/j. jenvman.2006.09.014

Filimonova, V.D., 1962. Kultura topoley za hranicey [The Poplar culture abroad]. Moskva: Goslesbumizdat. 134 p.

Fuchylo, Ya.D., Sbytna, M.V., Fuchylo, D.Ya., 2014. Osoblyvosti stvorennya plantatsiyi topoli $\mathrm{v}$ umovakh volohoho suhrudu [Features of creation of poplar plantations in moist sandy clay soil conditions]. Forestry and Forest Melioration, 125: 144-147.

Global Invasive Species Database (GISD), 2015. Species profile Populus alba. https://www.iucngisd.org/gisd/ species.php?sc=261

GonzÁlez, E., Comín, F.A., Muller, E., 2010. Seed dispersal, germination and early seedling establishment of Populus alba L. under simulated water table declines in different substrates. Trees, 24 (1): 151-163.

Harfouche, By.A., Baoune N., Merazga, H., 2007. Main and interaction effects of factors on softwood cutting of white poplar (Populus alba L.). Silvae Genetica, 56 (6): 287-294. https://doi.org/10.1515/sg-2007-0041

Henriksson, A., Henriksson, G., 2015. Rokwood: development of direct chipping harvesters for short rotation plantations by the Swedish family enterprise Henriksson Salix AB. Aspects of Applied Biology, 131: 45-52.

Holloway, J.V., Rillig, M.C., Gurnell, A.M., 2017. Underground riparian wood: reconstructing the processes influencing buried stem and coarse root structures of Black 
Poplar (Populus nigra L.). Geomorphology, 279: 199-208. https://doi.org/10.1016/j.geomorph.2016.07.027

Hrom, M.M., 2010. Lisova taksatsiya [Forest inventory]. Lviv: RVV NLTU. $416 \mathrm{p}$.

IsHChUK, L.P., 2016. Ispolzovaniye topoley (Populus L.) $\mathrm{v}$ urboyekosisteme goroda Belaya Tserkov [Using poplar (Populus L.) in urbanized ecosystem of Belaya Tserkov' Town]. Formation of Urban Green Areas, 1 (13): 142-150.

JAKUCS, E., 2002. Ectomycorrhizae of Populus alba L. in South Hungary. Phyton, 42 (2): 199-210.

Kaldorf, M., Renker, C., Fladung, M., Buscot, F., 2004. Characterization and spatial distribution of ectomycorrhizas colonizing aspen clones released in an experimental field. Mycorrhiza, 14: 295-306. https://doi.org/10.1007/s00572003-0266-1.

KASHPOR, S.M., STROChINSKIY, A.A., 2013. Lisotaksatsiyniy dovidnyk [Forest inventory directory]. Kyiv: Vinnichenko. $564 \mathrm{p}$.

Katanić, M., Grebenc, T., Orlović, S., Matavuly, M., Kovačević, B., Bajc, M., Kraigher, H., 2015. Ectomycorrhizal fungal community associated with autochthonous white poplar from Serbia. iForest Biogeosciences and Forestry, 9 (2): 330-336. https://doi. org/10.3832/ifor1370-008

KeČA, L., KeČA, N., Pantić, D., 2012. Net present value and internal rate of return as indicators for assessment of costefficiency of poplar plantations: a Serbian case study. International Forestry Review, 14 (2): 145-156. https:// doi.org/10.1505/146554812800923345

Klašnja, B., Orlović, S., Galić, Z., Drekić, M., 2006. Poplar biomass of short rotation plantations as renewable energy raw material. In Columbus, F. (ed.). Biomass and bioenergy new research. New York: Nova Science Publishers, p. 35-66.

Klopfenstein, N.B., Chun, Y.W., Kim, M.S., Ahuja, M.R., Dillon, M.C., Carman, R.C., Eskew, L.G., 1997. Micropropagation, genetic engineering, and molecular biology of Populus. General Technical Report, RM 297. Fort Collins: Rocky Mountain Forest and Range Experiment Station, USDA Forest Service. 326 p.

Korshikov, I., Danilchuk, N., Krasnoshtan, O., Mazur, A., 2008. Zhiznennaya forma i vehetativnoe razrastaniye topolya beloho (Populus alba L.) na zhelezorudnyh otvalah Krivorozhya [Life form and vegetative expansion of white poplar (Populus alba L.) on the iron ore dumps of Kriviy Rig]. Plant Introduction, 39: 105-112. https://doi. org/10.5281/zenodo.2560716

Kravchuk, V., Novokhatsky, M., Kozhushko, M., Dumich, V., ZHURBA, G., 2013. Na shlyakhu do stvorennya plantatsiy enerhetychnykh kultur [Towards the creation of energy crops]. AIC Technology and Technology, 2: 31-34. https:// nbuv.gov.ua/UJRN/Titapk_2013_2_14. [cit. 2020-04-01].

Lakida, P.I., Bilous, A.M., Vasilishin, R.D., TerentyeV, A.Yu., AtamanchuK, R.V., 2011. Khid rostu chystykh modalnykh derevostaniv myahkolystyanykh porid Polissya Ukrayiny [Growth of pure modal stands of softwood broadleaved species in Ukrainian Polissya]. Scientific Reports of NULES of Ukraine, 1 (23): 159-164.

Lakida, P.I., Laschenko, A.G., Laschenko, M.M., 2006. Biologichna produktyvnist dubovyh derevostaniv Podillya
[Biological productivity of oak stands in Podillya]. Kyiv: NNTs IAE. $196 \mathrm{p}$.

LaPaCh, S.N, Chubenco, A.V., BabYCh, P.N., 2001. Statisticheskiye metody $v$ biomeditsinskikh issledovaniyakh $s$ ispolzovaniyem Excel [Statistical methods in biomedical research using Excel]. Kyiv: Morion. 408 p.

Lavrinenko, D.D., RedKo, G.I., Lishenko, A.A., Kovalevskiy, A.K., Timchenko, G.A., 1966. Sozdaniye topolevykh nasazhdeniy [Creation of poplar plantations]. Moskva: Lesnaya promyshlennost'. $288 \mathrm{p}$.

LindegaARD, K.N., 2016. Short rotation plantations policy history in Europe: lessons from the past and recommendations for the future. Food and Energy Security, 5 (3): 125-152. https://doi.org/10.1002/fes3.86.

Maksimenko, A.P., Maksimtsov, D.V., Martynova, V.R., Nedelyaeva, C.V., Kholyavko, O.Yu., 2016. Itohi sorokaletnego sortoispytaniya hibridnykh topoley na peschano-rakushechnykh pochvakh Vostochnoho Priazovya [The results of forty-year-old variety-trial of hybridous poplars on the sandy soils of Eastern Azov Shelly]. Scientific Journal KubSAU, 124 (10): 181-200. https://doi.org/10.21515/1990-4665-124-009

Mashkina, O.S., Tabatskaya, T.M., Morkovina, S.S., PanYavina, E.A., 2016. Vyrashchivaniye posadochnoho materiala topolya beloho (Populus alba L.) na osnove kollektsiyi in vitro i otsenka yeho sebestoimosti [Growing seedlings White Poplar (Populus alba L.) based on the collection in vitro and evaluation of its cost]. Forestry Jjournal, 1: 28-44. https://doi.org/10.12737/18725.

Migunova, Ye.S., 2017. Lesnaya tipologiya v Ukraine [Forest typology in Ukraine]. Kharkiv: Planet- Print. 50 p.

Migunova, Ye.S., 2014. Tipy lesa $i$ tipy prirody. Ekologicheskiye vzaimosvyazi [Types of forests and types of nature. Environmental linkages]. Saarbrücken: Palmarium Academic Publishing. 295 p.

Miklush, S.I., 2007. Modelyuvannya rostu nasadzhen za materialamy povydilnoyi bazy danyh [Modeling of stands growth based on materials of the database]. Scientific Reports of NULES of Ukraine, 106: 191-200.

Newman, L.A., Strand, S.E., Choe, N., Duffy, J., Ekuan, G., Ruszaj, M., Shurleff, B.B., Wilmoth, J., Heilman, P., Gordon, M.P., 1997. Uptake and biotransformation of trichloroethylene by hybrid poplars. Environment, Science and Technology, 31: 1062-1067. https://doi.org/10.1021/ es960564w.

OSTAPENKO, B.F., TKACH, V.P., 2002. Lisova typolohiya [Forest typology]. Kharkiv: Pleyada. 204 p.

Palancean, I., Alba, N., Sabatti, M., Sven, M. G. DE VRIES., 2018. EUFORGEN technical guidelines for genetic conservation and use for common walnut (Populus alba). European Forest Genetic Resources Programme (EUFORGEN), European Forest Institute. 6 p.

Rebola-Lichtenberg, J., Schall, P., AnNighöFer, P., Ammer, C., Leinemann, L., Polle, A., Euring, D., 2019. Mortality of different Populus genotypes in recently established mixed short rotation coppice with Robinia pseudoacacia L. Forests, 10: 410-422. https://doi.org/10.3390/f10050410.

RÉDeI, K., KeSERÜ, Z., GÁBor, Z., 2010. Early evaluation of promising white poplar (Populus alba L.) clones in Hungary. Acta Silvatica et Lignaria Hungarica, 6: 9-16. 
RÉDEI, K., KESERÜ, Z., RÁSÓ, J., JuHÁSZ, L., GYŐRI, J., ANTAL, B., 2012. Growth and yield of mixed black locust (Robinia pseudoacacia L.) and white poplar (Populus alba L.) stands under sandy soil conditions in Hungary: a case study. Silva Balcanica, 13 (1): 20-29.

RÉDEI, K., VePerdi, I., MeILby, H., 2006. Stand structure and growth of mixed white poplar (Populus alba L.) and black locust (Robinia pseudoacacia L.) plantations in Hungary. Acta Silvatica and Lignaria Hungarica, 2: 23-32.

REDKo, G.I., 1975. Biolohiya i kultura topoley [Biology and culture of poplars]. Leningrad: Leningrad University. $175 \mathrm{p}$.

Rusin, N.S., 2008. Povysheniye produktivnosti lesov putem sozdaniya plantatsionnykh kultur bystrorastushchikh porod [Increasing the productivity of forests through the establishment of fastgrowing species plantation crops]. Forestry Information, 3-4: 27-28.

Rytter, L., Johansson, T. Karačić, A., Wein, M., 2011. Investigation for a Swedish research program on the genus Populus. Arbetsrapport / Skogforsk, 733. Uppsala: Skogforsk. 148 p.

SChweIER, J., 2012. Harvesting of short rotation coppice harvesting trials with a cut and storage system in Germany. Silva Fennica, 46 (2): 287-299. https://www.metla.fi/ silvafennica/full/sf46/sf462287.pdf. [cit. 2020-03-11].

Stanturf, J.A., Oosten, C., Netzer, D.A., Coleman, M.D., PorTwood, C.J., 2001. Ecology and silviculture of poplar plantations. In Poplar culture in North America. Ottawa: NRC Research Press, p. 153-206.

Starova, N.V., 1962. Metodika selektsii i sortoispytaniya topoley [Method of selection and variety testing of poplars]. Kharkiv: UkrNIILHA. 60 p.

Strenge, E., Thevs, N., Aliev, K., Eraaliev, M., Lang, P., Baibagysov, A., 2018. Water consumption of Populus alba trees in tree shelterbelt systems in Central Asia a case study in the Chui Valley, South Eastern Kazakhstan. Central Asian Journal of Water Research, 4 (1): 48-62. https://doi.org/10.29258/CAJWR/2018-RI.v4-1/48-62.eng

TARAN, G.S., DyaChENKo, A.P., 2018. Topolevyye lesa reki Obi u goroda Kolpashevo (Tomskaya oblast, Rossiya) [Poplar forests of the Ob River near the town of Kolpashevo, Tomsk Region, Russia]. Journal of Siberian Federal University. Biology, 12 (1): 12-31. https://doi.org/10.17516/19971389-0064.

TкACH, V.P., 1999. Zaplavni lisy Ukrayiny [Floodplain forest of Ukraine]. Kharkiv: Pravo. 368 p.

Tsarev, A.P., Tsareva, R.P., Tsarev, V.A., 2010. Dinamika sokhrannosti i produktivnosti nastoyashchikh topoley pri ispytanii $\mathrm{v}$ usloviyakh umerennoho klimata [Dynamics of safety and productivity of these poplars at IC tests in temperate climates]. Information Bulletin VOGiS, 14 (2): 659-668.

Tullus, A., Rytter, L., Tullus, T., Weih, M., Tullus, H., 2012. Short-rotation forestry with hybrid aspen (Populus tremula L. $\times$ P. tremuloides Michx.) in Northern Europe. Scandinavian Journal of Forest Research, 27 (1): 10-29. https://doi.org/10.1080/02827581.2011.628949

Vedmid, M.M., Meshkova, V.L., ZheZhrun, A.M., 2006. Alhorytm dlya vyyavlennya dilyanok malotsinnykh molodnyakiv u dibrovakh za materialamy lisovporyadkuvannya [Algorithm for reveal of low valuable young stands in the oakeries by forest inventory data]. Forestry and Forest Melioration, 110: 54-58.

VysotsKa, N.Yu., 2017. Suchasnyy stan i perspektyvy zberezhennya henetychnykh resursiv topoli $\mathrm{v}$ Ukrayini [Current state and prospects of the poplar genetic resources conservation in Ukraine]. Proceedings of the Forestry Academy of Sciences of Ukraine, 15: 38-44. https://doi. org/10.15421/411705

VysotsKa, N.Yu., KoBets, O.V., 2018. Osoblyvosti rostu ta formuvannya pryrodnykh poroslevykh derevostaniv osyky yevropeyskoyi (Populus tremula L.) [Specificities of growth and formation of the European aspen (Populus tremula L.) natural coppice stands]. Forestry and Forest Melioration, 134: 3-12. https://doi.org/10.33220/10263365.134.2019.3.

Vysotska, N.Yu., Tкасн, V.P., 2016. Derevostany topoli ta osyky v Ukrayini [Poplar and aspen stands in Ukraine]. Forestry and Forest Melioration, 128: 20-27.

Wang, Y., BaI, G., Shao, G., CaO, Yu., 2014. An analysis of potential investment returns and their determinants of poplar plantations in state-owned forest enterprises of China. New Forests, 45 (2): 251-264. https://doi. org/10.1007/s11056-014-9406-z.

Wilske, B., Lu, N., Wei, L., Chen, S., Zha, T., Liu, C., Xu, W., Noormets, A., Huang, J., Wei, Y., Chen, J., Zhang, Z., Ni, J., Sun, G., Guo, K., McNulty, S., John, R., Han, X., LIN, G., CHEN, J., 2009. Poplar plantation has the potential to alter the water balance in semiarid Inner Mongolia. Journal of Environmental Management, 90: 2762-2770. https://doi.org/10.1016/j.jenvman.2009.03.004.

ZSUFFA,L., 1993. Proposal for establishment and implementation of a certification service for poplar and willow planting stool. Poplar Council of Canada Newsletter, 4: 4-6.

Received April 29, 2020 Accepted August 27, 2020 